\title{
Uptake and Release of Phosphorus from Polyphosphate Bodies by Synechococcus leopoliensis.
}

John Hagan Brown and T. E. Jensen

Department of Biological Sciences, Lehman College, Bronx NY 10468, and the Graduate Center (CUNY), NY, NY 10016.

Biological phosphorus removal is an accepted phenomenon applied to reduce phosphorus concentrations from wastewaters-activated sludge process with alternating anaerobic/aerobic conditions. The anaerobic-aerobic processes have been successfully used for enhanced biological phosphorus removal (EBPR) as reported by Mino et al (1) and Smolder et al. (2) in recent years. Other findings in the laboratory reported by Jensen (3), and McGrath et al. (4) have indicated that under aerobic conditions some heterotrophic organisms store polyphosphate intracellularly. The phosphorus serves as an energy source during periods of starvation. The objective of this study was to investigate polyphosphate accumulation and the release of phosphorus by Synechococcus leopoliensis under anaerobic and aerobic conditions. The cells of Synechococcus leopoliensis were grown to log phase and to the Overplus phase in Modified Fitzgerald Medium (MFM) at pH 7.2 in $250 \mathrm{~mL}$ Emery flasks. Cells were harvested when they reached the logarithmic growth phase in 14 days and washed $3 \mathrm{x}$ with phosphorusfree medium (MFM-PO4) and grown in MFM-PO4 for 5 days for the purpose of starving the cells. Cells were spun down and resuspended in complete medium (MFM+PO4) in the 250-mL Emery flasks. The flasks were completely covered with aluminum foil to eliminate light. Nitrogen gas was pumped in at 10 pounds per square inch (PSI) for 30 minutes $4 \mathrm{x}$ a day for 4 days. Cell count was done using the Spectrophotometer 20 (no data shown). Cells were drawn out using 20gauge syringe and put in 20 vials for counting. Negatives of cells from the anaerobic and aerobic Overplus conditions were taken using the Hitachi H-7000 electron microscope. Cell volume and PPB volume were calculated from prints produced from the negatives. Extracellular orthophosphate concentrations were determined using a Hach Orthophosphate Test Kit (Reactive High Range). Findings confirmed that when cells of Synechococcus leopoliensis were starved from their essential nutrients (phosphorus) for a period of time and resuspended in their nutrient rich environment, they take up phosphorus. The experiment showed that Synechococcus leopoliensis is good for phosphorus removal under anaerobic conditions. Volume of PPBs under anaerobic condition for time period was reduced. In general, Synechococcus leopoliensis is a good microbe for the release of phosphorus under anaerobic conditions.

References:

1. Mino T. et al. Pergamon Press. Oxford (1987) 22-38.

2. Smolder G. J. F., et al., Biotechnology and Bioengineering 43(1993) 461-470.

3. T. E. Jensen et al., Environmental Pollut. Ser A 27(1982). 
5. I. Yall et al., Applied Microbiology 20(1970) 145-150.

\section{Figure 1}

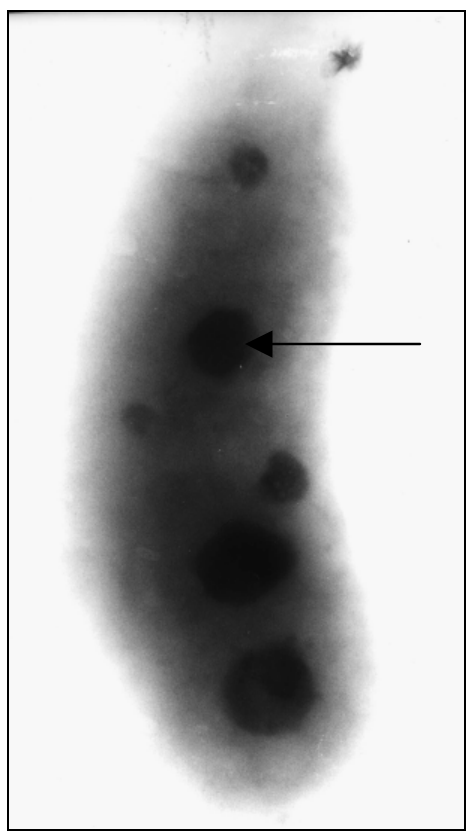

\section{Figure 2}

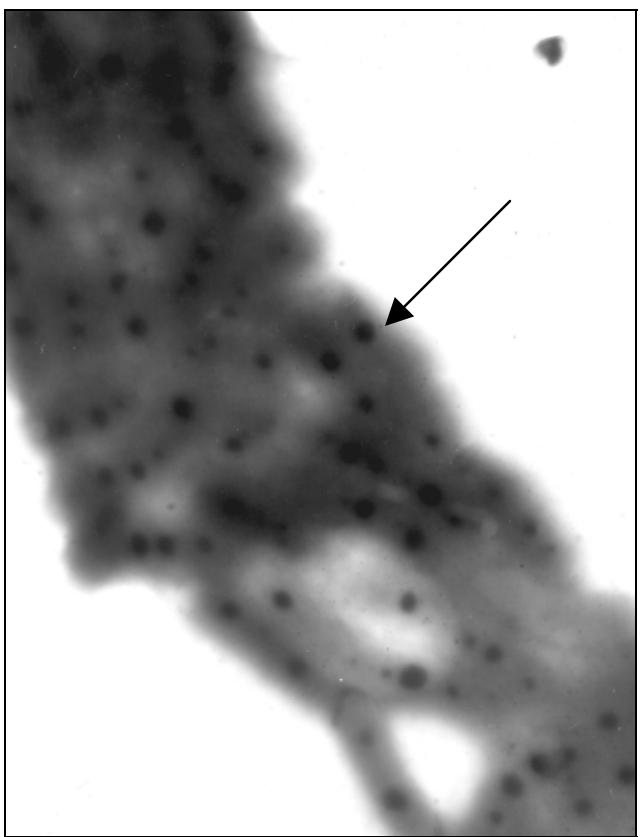

\section{Figure 3}

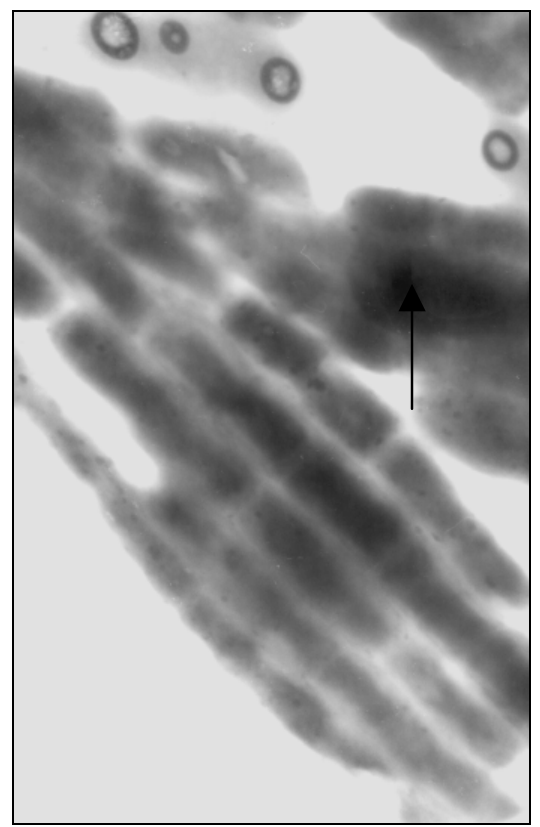

Table 1

\begin{tabular}{|l|l|l|l|}
\hline $\begin{array}{l}\text { MFM } \\
\text { Condition }\end{array}$ & $\begin{array}{l}\text { Time } \\
\text { (days) }\end{array}$ & $\begin{array}{l}\text { Per cent P } \\
\text { Released }\end{array}$ & $\begin{array}{l}\text { Per cent } \\
\text { Volume of } \\
\text { PPB }\end{array}$ \\
\hline Normal & 14 & 20 & 25 \\
\hline Starved & 5 & 35 & 10 \\
\hline $\begin{array}{l}\mathrm{N}_{2} \\
\text { Bubbled }\end{array}$ & 4 & 85 & 2 \\
\hline & & & \\
\hline
\end{tabular}

Figure 1. Shows the amount and size of PPBs at normal growth and the Overplus phenomenon. During normal growth, PPBs are larger in the cell. Arrows show PPBs. X 26,000.

Figure 2. PPBs are smaller in size and widely distributed all over the cell. $\mathrm{X} 28,000$. X 28000

Figure 3. Shows the anaerobic condition. Most of cells possess no PPBs.

Table 1. The release of phosphorus by cells of Synechococcus leopoliensis under the anaerobic, aerobic, and starvation periods. 